and diphenhydramine ${ }^{2}$ have shown no advantage over placebo from the point of view of patient or doctor. In a brief experience so far our patients appear to have tolerated examinations satisfactorily without any pharyngeal anaesthesia. It may thus be unnecessary as well as potentially dangerous.I am, etc.,

St. Thomas's Hospital,

P. B. Cotton

London S.E.

1 Buchanan, D. P., American fournal of Digestive Diseases, 1960, 5, 121.

Spournal of Digestive Diseases, 1967, American

\section{Harry's Angels}

SIR,-How refreshing to read the story from South Africa under the title "Harry's Angels" (4 November, p. 288). It lifts one's spirit to hear of a team of highly-skilled specialists from Johannesburg who sacrifice their leisure weekends to travel by air to and from Swaziland (that small country with one doctor to 8,000 patients) in order to create, at their own expense, a first-class free medical and surgical service there, until such time as the country can supply its own needs. - I am, etc.,

Hove, Sussex

OLIVE K. BURNETT

\section{Foley-catheter Induction of Labour}

SIR,-The method described by Mr. J. R. Saunders (28 October, p. 237) deserves to be widely known. It has the great advantage of not compromising the patient's physical or mental condition. Further, when delivery is not urgent and there is time for its leisurely employment, it is, in cases when the cervix is unfavourable, a most effective insurance against failure of induction.

The patient is hardly aware of the catheter after its insertion. The membranes have not been ruptured; there is no risk of sepsis. There is no prolonged period of draining liquor and the patient is not attached to an oxytocin infusion or sucking Pitocin tablets by day and unable to take her normal meals. A course common with induction with the unripe cervix, which is encouraged by anxiety and starvation and which leads to acidosis and incoordinate labour, is never begun. The Foley catheter does not compromise the fetal condition. Oxytocin infusion, buccal Pitocin, and amniocentesis can all adversely affect it sooner or later.

The method has great value in cases where the patient has previously been subjected to caesarean section for inco-ordinated uterine action. I have concluded that there have been many cases when this method of induction might have avoided the original operation.-I am, etc.,

Shaw, Near Swindon

W. G. Dawson Wilts

\section{The "Dysarthria Address"}

SIR,-Throughout various medical centres in the world and particularly in hospitals in the United Kingdom the patient is asked to say "37 West Register Street, Edinburgh," one of the common phrases used in testing for dysarthria. During a recent visit to Edinburgh I decided to determine what is located at that famous address.
Following West Register Street from Saint Andrew's Square the numbers ceased in the 40s and continued from 19 somewhat further down the street. Occupying most of this numberless gap was an office building with a temporary sign pasted on its door. The inhabitants of the building did not know its street number, and therefore the query was referred to the supervisor. With puzzled look, he admitted that they only recently had transferred their office to the present location and ruefully noted that he did not know the number of the building. His curiousity aroused, we walked up and down West Register Street together trying to decide where " 37 " would be. We concluded that it was one of the many numbers encompassed by the building housing his office.

If so, 37 West Register Street is one of of the Royal Bank of Scotland.-I am, etc.,

George J. Dohrmann

The National Hospital, Queen Square,

London W.C. 1

\section{Association between Anaemia and Hypolipidaemia}

SIR,-The paper by Professors L. E. Böttiger and L. A. Carlson (23 September, p. 731) is of interest since it suggests a hypothesis known but hitherto unexplained association between anaemia and hypolipidaemia. The hypothesis assumes a constant total blood volume and a constant plasma cholesterol pool size, so that an increase in packed cell volume (P.C.V.) produces a rise in plasma cholesterol concentration secondary to the contraction in plasma volume.

Professors Böttiger and Carlson studied subjects with haemoglobin values in the normal range, and it is not known if their conclusions can be extrapolated to the anaemic situation. Data collected for a different purpose from five subjects with pernicious anaemia, at the time of diagnosis and in the Table below together with the change in serum cholesterol which would have been predicted by the Böttiger-Carlson hypothesis.

In every case the observed increase in plasma cholesterol exceeds that predicted by the Böttiger-Carlson hypothesis, and overall the observed increase is of the order of twice the predicted increase. Professors Böttiger and Carlson were careful to state that their hypothesis "may in part account for the positive correlation between haemoglobin and plasma lipids" [my italics], and the data given here suggest that it may indeed be necessary to postulate an alteration in either or both of total blood volume and plasma cholesterol the addresses of the Public Relations Office which may explain, at least in part, the longduring response to treatment, are given

pool size to explain the rise in plasma cholesterol concentration which occurs when anaemia is treated. Huber, Lewis, and Szur ${ }^{1}$ found little evidence of any change in total blood volume over the P.C.V. range $20-50 \%$, so it seems likely that there is an increase in plasma cholesterol pool size when anaemia is treated, but clearly more direct evidence is needed before this can be stated unequivocally.-I am, etc.,

Royal Posgtraduate Medical Schoo J. P. Miller London, W. 12

1 Huber, H., Lewis, S. M., and Szur, L., British fournal of Haematology, 1964, 10, 567.

\section{Infertility after the Pil}

SIR,-Your leading article on infertility after the pill (14 October, p. 59) reminds me that a few years ago you published a letter from me, ${ }^{1}$ the gist of which was to point out the possibility of this in certain cases.

My view ${ }^{2}$ has always been that there is an appreciable number, if a small percentage, of young and apparently normal women in whom some degree of hormonal dysfunction exists resulting in endometrial change and merstrual disturbance unrecognizable by the individual. This group is at risk in coping with the interference with the function of the hypothalamus consequent upon taking the pill over a lengthy period of time. In such cases the prolonged and somewhat unpredictable treatment by clomiphene and pituitary gonadotrophin cannot be altogether satisfactory.

In order to minimize the possibility of lifelong disappointment in these women $I$ suggest that a pelvic examination, and a diagnostic curettage if necessary, be carried out in all cases exhibiting the slightest menstrual irregularity before prescribing the pill. If such a procedure is impracticable I think these cases will increase in number in these days in which oral contraceptives are regarded as a universal panacea.-I am, etc.,

Altrincham, Cheshire

K. VERnon BAILEY

1 Bailey, K. V., British Medical fournal, 1969, 1, 2 Bailey, K. V., Fournal of Obstetrics and Gynaecology of the British Empire, 1959, 66, 556.

\section{Tumours of the Salivary Glands}

SIR,-Salivary tumours occur predominantly in the parotid gland, and the advances in parotid surgery in the past quarter-century have largely solved the problem of treatment of all except the uncommon highly malignant tumours of this organ. These advances have depended on the adoption of the

\begin{tabular}{|c|c|c|c|c|c|}
\hline Patient & P.C.V. & $\underset{\%}{(100-P . C . V .)}$ & $\begin{array}{c}\text { Plasma } \\
\text { Cholesterol } \\
\mathrm{mg} / 100 \mathrm{ml}\end{array}$ & $\begin{array}{l}\text { Change in } \\
\text { Plasma } \\
\text { Cholesterol } \\
\text { mg/100 ml }\end{array}$ & $\begin{array}{c}\text { Predicted Change } \\
\text { in Plasma } \\
\text { Cholesterol } \\
\text { mg/100 ml }\end{array}$ \\
\hline H.C. & $\begin{array}{l}15 \\
28 \\
41\end{array}$ & $\begin{array}{l}85 \\
72 \\
59\end{array}$ & $\begin{array}{l}115 \\
157 \\
205\end{array}$ & $\begin{array}{r}0 \\
+42 \\
+90\end{array}$ & $\begin{array}{r}0 \\
+21 \\
+51\end{array}$ \\
\hline J.D. & $\begin{array}{l}29 \\
46\end{array}$ & $\begin{array}{l}71 \\
54\end{array}$ & $\begin{array}{l}178 \\
264\end{array}$ & $\begin{array}{r}0 \\
+86\end{array}$ & $\begin{array}{r}0 \\
+56\end{array}$ \\
\hline G.R. & $\begin{array}{l}36 \\
47\end{array}$ & $\begin{array}{l}64 \\
53\end{array}$ & $\begin{array}{l}199 \\
281\end{array}$ & $\begin{array}{r}0 \\
+82\end{array}$ & $\begin{array}{r}0 \\
+41\end{array}$ \\
\hline J.B. & $\begin{array}{l}23 \\
40\end{array}$ & $\begin{array}{l}77 \\
60\end{array}$ & $\begin{array}{l}158 \\
293\end{array}$ & $\begin{array}{r}0 \\
+135\end{array}$ & $\begin{array}{r}0 \\
+45\end{array}$ \\
\hline I.Q. & $\begin{array}{l}28 \\
33 \\
37 \\
40\end{array}$ & $\begin{array}{l}72 \\
67 \\
63 \\
60\end{array}$ & $\begin{array}{l}120 \\
139 \\
157 \\
211\end{array}$ & $\begin{array}{r}0 \\
+19 \\
+37 \\
+91\end{array}$ & $\begin{array}{r}0 \\
+9 \\
+17 \\
+24\end{array}$ \\
\hline
\end{tabular}


fundamental surgical principle of adequate exposure and the recognition that identification of the facial nerve is (again apart from the highly malignant tumours) an essential part of such exposure. Having achieved adequate exposure, the surgeon is in the position to apply the fundamental surgicopathological principle of treatment of tumours-removal with such margin as the pathology demands. $\mathrm{He}$ is also in the best position to preserve, whenever the pathology allows (which is in most cases), importan structures such as the facial nerve. All the rest is merely a matter of detailed technique.

May I comment on one sentence in your leading article (4 November, p. 252) in which you refer to the advocacy of radiotherapy "for very frail patients [and] those with a recurrence after surgery. . ..." Operations for parotid tumour, though often technically tedious and therefore timeconsuming, are not upsetting to the patien -certainly much less so than intensive radiotherapy. Moreover, though radio therapy may be a valuable ancillary to surgery in the treatment of muco-epidermoid and adenoid-cystic carcinomas (contrary to what you say, the latter are radiosensitive), the cure by radiotherapy alone of any tumour of the salivary glands, primary or recurrent, is an exceptional rarity.-I am, etc.,

London W.1

David Patey

\section{Transient Cranial Mononeuropathy}

SIR,-The interesting paper by Dr. J. N. Blau and Mr. R. Kapadia (4 November, p. 259 ) on isolated benign recurrent laryngeal nerve palsy brings to mind a similar problem I encountered earlier this year.

The patient, a 61-year-old man, had previously been quite well apart from mild chronic bronchitis. Two days before admission he developed a cough which was particularly troublesome at meal times. The next day he noticed difficulty in swallowing solids and over the course of a few hours the dysphagia became complete. Food seemed to stick in the back of his throat and was regurgitated with difficulty and occasionally nasally. Coughing was unimpaired but his voice had become slightly hoarse over this same period.

On examination there was impaired movement of the left palate. Laryngoscopy showed pooling of saliva in the left pyriform fossa and total immobility of the left vocal cord and hemilarynx. The gag reflex was intact. There were no other obvious neurological abnormalities and general examination was normal. The possibility of mediastinal malignancy was intensively investigated with negative results. In particular, chest $\mathrm{x}$-ray, hilar tomography, bronchoscopy, oesophagoscopy, cerebrospinal fluid examination, and sputum cytology and culture were all normal.

During the first few days of the patients illness aspiration pneumonia complicated the picture despite feeding via a nasogastric tube and frequent pharyngeal suction. This was effectively dealt with, and 10 days after admission the dysphagia began to improve and his voice became less hoarse. Two weeks later he was able to eat solids and speak normally and indirect laryngoscopy showed return of movement to the paralysed vocal cord. For the past nine months he has boen seen frequently in the outpatient clinic. There has been no recurrence of symptoms and his general health seems good.

This man would appear to have suffered a benign cranial mononeuropathy involving the left vagus nerve. However, in this instance involvement was not confined to the recurrent laryngeal branch and dysphagia was the most obtrusive symptom, with dysphonia a significant but less important accompaniment. One of the patients reported by Blau and Kapadia also had transient dysphagia, but its severity was not mentioned. The present patient showed another difference in that the onset of his symptoms was more acute and resolution more rapid. Unfortunately virus studies were not carried out and no valid comment about a possible viral cause can be made, though clinically there was nothing to suggest such an association.-I am, etc.,

Withington Hospital,

H. M. PALMER

West Didsbury, Manchester

\section{Haemolytic Anaemia with Nalidixic Acid}

SIR,-The case of haemolytic anaemia due to nalidixic acid reported by Drs. L. Alessio and G. Marselli (14 October, p. 110) and the two other published cases cited by them ${ }^{12}$ seem to show a variety of haematological mechanisms. We wish to report a case with fatal outcome in which nalidixic acid would appear to have been the responsible agent.

A 65-year-old woman had complained of abdominal pain, vomiting, and dysuria for a few days, and on admission to hospital was profoundly anaemic and jaundiced. She had received nalidixic acid and prochlorperazine from the outset and after 48 hours had become icteric. There was history of similar symptoms, ascribed to urinary tract infection, for the previous 18 months and on a number of occasions she had received courses of nalidixic acid. Her own doctor recollected that she had developed transient jaundice after the penultimate administration of the drug, three months before admission.

Laboratory investigation showed a haemo globin level of $49 \%$ and W.B.C. of $27,300 / \mathrm{mm}$, with $94 \%$ polymorphs. Reticulocyte count was $4 \%$. Red cells were spherocytic with marked polychromasia, and nucleated red cells accounted for $6 \%$ of the "nucleated cell" count. Direct Coombs test was strongly positive. Fibrinogen level was normal and the blood clotting ratio was 1.8 (normal 1.0). Schumm's test was positive and the serum glucose-6-phosphate dehydrogenase level normal. Serum total bilirubin was $12.6 \mathrm{mg} / 100 \mathrm{ml}$, with a direct reading of 1.4 $\mathrm{mg} / 100 \mathrm{ml}$.

In spite of large doses of hydrocortisone, ampicillin, and kanamycin and blood transfusion the condition deteriorated, with peripheral circulatory failure and a rising blood urea, and she died 72 hours after admission. Permission for necropsy was not granted.

We feel that the autoimmune haemolytic anaemia in this case could be directly attributed to therapy with nalidixic acid Certainly the rapidity of onset of this illness, shortly after commencing treatment with the drug, and the additional evidence of her general practitioner, who noticed jaundice following a previous course of therapy, would support this view. By analogy with "methvldopa haemolytic anaemia" duration of therapy seems to be an important factor, and in this case intermittent courses of the drug appeared to be responsible for the development of an autoimmune state. The previously reported cases have had relatively short exposure resulting in a "chemical" haemolytic anaemia, and in two of the three there was a deficiency of glucose-6-phosphate dehydrogenase. Experience with the present patient suggests that care should be taken in the long-term use of this drug, and inquiry about jaundice connected with previous administration would seem to be a necessary precaution.-We are, etc.,

\section{Gilbertson}

D. ROWLEY JONES

Nevill Hall Hospital,

1 Bolton, E. M. and Vaughan Jones, R., Lancet,

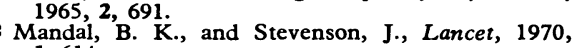
1,614 .

\section{Acute Myeloblastic Leukaemia during Pregnancy}

SIR,-Pawlinger and others ${ }^{1}$ and Maurer and others $^{2}$ have published contradictory views on the effect of cytosine arabinoside and thioguanine on the fetus. The latter reported trisomy for group C autosomes when large doses were given in the second trimester of pregnancy. We would like to report a further case.

A 20-year-old woman was admitted to hospital in March 1972 complaining of tiredness, breathlessness, and increasing pallor. Her $\mathrm{Hb}$ was 3.6 g/100 ml, W.B.C. $33,600 / \mathrm{mm}^{3}$, with $86 \%$ myeloblasts and $1 \%$ myelocytes, and a platelet count of $25,000 / \mathrm{mm}^{3}$. Sternal bone marrow con firmed the diagnosis of acute myeloblastic leukaemia. Fetal movements had been felt and pregnancy was estimated to be 32 weeks. A modified but somewhat similar treatment regimen to that used by Guyer and others, ${ }^{3}$ was chosen because of difficulties in management and because of the gentler approach to therapy. Bearing in mind the possibility of chromosomal abnormality and the patient's religious objection to termination, she was given the following course of therapy as well as prednisolone $30 \mathrm{mg}$ daily: days 1 to 5 , cytosine arabinoside $80 \mathrm{mg} / \mathrm{m}^{2}$ intravenously; days 6 to 11 , rest period; days 12 to 17 , thioguanine $70 \mathrm{mg} / \mathrm{m}^{2}$ orally. Only two cycles of treatment were given between the 33rd and 37th week of pregnancy, at the end of which period the peripheral blood picture showed $\mathrm{Hb} 10.2 \mathrm{~g} / 100 \mathrm{ml}$ and W.B.C. $4000 / \mathrm{mm}^{3}$, with $2 \%$ myeloblasts and $2 \%$ myelocytes. The platelet count had risen to $105,000 / \mathrm{mm}^{3}$.

Labour was induced on 9 May 1972 and the patient had a normal delivery of a normal male infant weighing $2,948 \mathrm{~g}$, whose appearance was consistent with a gestational age of 38 weeks. Venous blood on the first day showed Hb $14.1 \mathrm{~g} / 100 \mathrm{ml}$, W.B.C. $23,000 / \mathrm{mm}^{3}$, with $73 \%$ plymorphs, $23 \%$ lymphocytes, $4 \%$ monocytes, and a platelet count of $140,000 / \mathrm{mm}^{3}$ Repeated estimations gave results within the normal range. A chest radiograph showed no thymus shadow. Blood urea and electrolytes were normal. Chromosome analysis showed normal male karyotype with no breaks observed. After 48 hours the baby developed a typical physiological jaundice (maximum total bilirubin $13.5 \mathrm{mg} / 100 \mathrm{ml}$ ), which lasted eight days.

Nicholson ${ }^{4}$ reported that the risk of congenital abnormality in the fetus resulting from treatment after the first trimester was no greater than normal. Our cytosine-thioguanine regimen was chosen after discussion with Professor E. K. Blackburn because only small doses of the two drugs were required. We were unable to induce marrow remission in the mother but she remained well throughout the pregnancy. In the puerperium she developed an $E$.coli urinary tract infection with septicaemia which was resistant to intensive antibiotic therapy, and the patient succumbed. The baby, now 5 months old, is developing normally.

We are indebted to Dr. C. P. Alexander and Mr. J. A. Riedel, of Leicester Royal Infirmary, 